\title{
Study of serum lactate dehydrogenase level and seasonal variation in preeclampsia and eclampsia with its obstetric outcome
}

\author{
Shilpa S. Ciryam*, Gomathy E.
}

Department of Obstetrics and Gynecology, Sri Devaraj Urs University, Kolar, Karnataka, India

Received: 01 June 2017

Accepted: 27 June 2017

\section{*Correspondence:}

Dr. Shilpa S. Ciryam,

E-mail: shilpaciryam90@gmail.com

Copyright: () the author(s), publisher and licensee Medip Academy. This is an open-access article distributed under the terms of the Creative Commons Attribution Non-Commercial License, which permits unrestricted non-commercial use, distribution, and reproduction in any medium, provided the original work is properly cited.

\begin{abstract}
Background: Preeclampsia and eclampsia complicate $6-8 \%$ of all pregnancies and lead to various maternal and fetal complications. LDH is an intracellular enzyme and its level is increased in this women due to cellular death. So, serum LDH levels can be used to assess the severity of disease, to improve the maternal and fetal outcome. Studies in several countries have shown higher incidence of the disease in the winter season. This study is being conducted to correlate serum LDH levels and seasonal variation in preeclampsia and eclampsia.

Methods: It is a retrospective observational study. Data for 102 cases were collected from the parturition register and patient discharge record from January to December 2016. All singleton pregnant women who came to R L Jalappa Hospital with severe preeclampsia and eclampsia were included in the study.

Results: Total of 102 patients were studied. Incidence of the disease was most commonly seen in younger age group, which was statistically significant $(\mathrm{p}=0.020)$. Even though most of the cases presented in winter (39), there was no statistically significant association between seasonal variation in occurrence of the disease and serum LDH levels. $\mathrm{LDH}$ raised to $>800 \mathrm{IU} / \mathrm{L}$ in the cases was seen more in the younger age group.

Conclusions: This study only showed that preeclampsia and eclampsia occurred most commonly in younger women. This study did not show any variation in serum LDH levels in patients presenting in different seasons.
\end{abstract}

Keywords: Eclampsia, LDH, Preeclampsia, Seasonal variation

\section{INTRODUCTION}

Preeclampsia is a pregnancy specific syndrome that can virtually affect every organ system, occurring after 20 weeks of gestation. It is a progressive disease with a variable mode of presentation and rate of progression. It is one of the leading causes of maternal and fetal morbidity and mortality. Eclampsia is convulsions occurring in a preeclamptic woman, which cannot be attributed to another cause. ${ }^{1,2}$

Preeclampsia and eclampsia complicate $5-8 \%$ of all pregnancies. Although the precise etiology is not clear, defective placentation and endothelial dysfunction are found to be the cause of hypertension, proteinuria and edema. $^{3}$

Lactate dehydrogenase (LDH) is an intracellular cytoplasmic enzyme that converts lactic acid to pyruvic acid. LDH is ubiquitous to all major organ systems. Elevated levels indicate cellular death and leakage of enzyme from cells. Serum LDH is abnormal in a host of disorders therefore the total serum LDH is highly sensitive but not specific test. High levels of LDH were found in severe preeclampsia and eclampsia. Thus, LDH was used to assess the severity of the disease, which 
further helped to make decision regarding management to improve maternal and fetal outcome. ${ }^{3-5}$

The pathogenesis of preeclampsia and eclampsia is poorly understood. The role of seasonal variation in its aetiology is one of the factors being considered. According to various studies done across the world, seasonal variation in the occurrence of preeclampsia and eclampsia specific to the country was observed. ${ }^{6}$

As the association of serum LDH levels and severity of preeclampsia and eclampsia and also the seasonal variation in the etiology of the disease has been studied before, the aim of this study was to compare serum $\mathrm{LDH}$ levels with seasonal variation in preeclampsia and eclampsia associated with its obstetric outcome.

Objectives of present study were to investigate the correlation of maternal and perinatal outcomes with serum LDH levels in preeclampsia and eclampsia patients and to compare serum LDH levels in preeclampsia and eclampsia patients presenting in different seasons.

\section{METHODS}

A retrospective observational study was conducted in the Department of Obstetrics and Gynecology, R L Jalappa Hospital and Research Centre, Kolar. Data was collected from the parturition register and patient discharge record from January 2016 to December 2016. In the present study 100 patients were included and divided into preeclampsia and eclampsia.

Subjects were further subdivided according to the serum LDH levels into following groups: <600 IU/1, 600-800 IU/1 and >800 IU/1. According to the month of delivery into following groups: November to January (winter), February to May (summer) and June to October (rainy). ${ }^{7}$

\section{Inclusion criteria}

- $\quad$ Singleton pregnancy

- $\quad$ Age 18 - 37 years.

- Preeclamptic and eclamptic women whose blood pressure was normal during first 20 weeks of gestation

- No previous history of hypertension.

- All the cases were in the third trimester of pregnancy (>28wk of gestation).

\section{Exclusion criteria}

- Patients with diabetes, renal failure, haemolytic anemias, chronic hypertension, gestational diabetes, multiple pregnancy, smoking and alcoholism, liver disease, hepatotoxic drugs, stroke, coronary artery disease, chronic lung diseases, connective tissue disorders, disseminated intravascular coagulation and seizures, were excluded

\section{Statistical analysis}

SPSS version 20 was used for statistical analysis. Frequency and percentages represented in tabular form. Chi square test and Fisher exact test were used to test the statistical significance.

\section{RESULTS}

Total of 102 patients were studied, out of which 50 were preeclamptic and 52 were eclamptic. Incidence of the disease was most commonly seen in younger age group (18-27 years), which was statistically significant $(\mathrm{p}=0.020)$. There was no significant difference in patients with preeclampsia and eclampsia when compared to period of gestation, parity and moth of delivery and mode of delivery (Table 1).

Table 1: Distribution of preeclamsia and eclampsia cases.

\begin{tabular}{|c|c|c|c|c|c|c|}
\hline & & Preeclampsia $(\mathrm{n}=50)$ & Eclampsia $(n=52)$ & Total $(n=102)$ & $\%$ & $P$ value \\
\hline \multirow{4}{*}{$\begin{array}{l}\text { Age } \\
\text { categories }\end{array}$} & $18-22$ & 13 & 28 & 41 & 40.1 & \multirow{4}{*}{0.020} \\
\hline & $23-27$ & 26 & 14 & 40 & 39.2 & \\
\hline & $28-32$ & 7 & 8 & 15 & 14.7 & \\
\hline & $33-37$ & 4 & 2 & 6 & 5.8 & \\
\hline \multirow{3}{*}{$\begin{array}{l}\text { Gestational } \\
\text { age }\end{array}$} & $14+1$ to 28 & 0 & 3 & 3 & 2.9 & \multirow{3}{*}{0.071} \\
\hline & $28+1$ to 37 & 34 & 26 & 60 & 58.8 & \\
\hline & $37+1$ to $>40$ & 16 & 23 & 39 & 38.2 & \\
\hline \multirow{3}{*}{ Parity } & Primigravida & 27 & 29 & 56 & 54.9 & \multirow{3}{*}{0.485} \\
\hline & Gravida 1 and 2 & 11 & 15 & 26 & 25.4 & \\
\hline & Gravida 3 to 5 & 12 & 8 & 20 & 19.6 & \\
\hline \multirow{3}{*}{$\begin{array}{l}\text { Delivery } \\
\text { month }\end{array}$} & March to May & 9 & 19 & 28 & 27.4 & \multirow{3}{*}{0.084} \\
\hline & June to Oct & 21 & 14 & 35 & 34.3 & \\
\hline & Nov to Feb & 20 & 19 & 39 & 38.2 & \\
\hline \multirow{2}{*}{$\begin{array}{l}\text { Mode of } \\
\text { delivery }\end{array}$} & Vaginal & 28 & 20 & 48 & 47.1 & \multirow{2}{*}{0.076} \\
\hline & LSCS & 22 & 32 & 54 & 52.9 & \\
\hline
\end{tabular}


Low birth weight was seen in 53 out of 66 cases of raised LDH (>800) and NICU admissions were seen in 39 of 66 cases. Even though low birth weight and NICU admissions were more when LDH level was more than 800IU/L, it was not statistically significant. Higher LDH levels in cases did not show a significant difference in the occurrence of low APGAR score, IUD, stillbirth and neonatal death (Table 2). Out of 102 cases, 28 delivered in summer (March to May) - 9 were preeclamptic and 19 were eclamptic. 35 patients delivered in rainy season (June to October) - 21 were preeclamptic and 14 were eclamptic. 39 deliveries were in winter (November February) - 20 were preeclamptic and 19 were eclamptic. Even though most of the cases presented in winter, there was no statistically significant association between seasonal variation in occurrence of the disease and serum LDH levels, $(\mathrm{p}=0.8)$ (Table 3).

Table 2: Serum LDH levels and perinatal outcome.

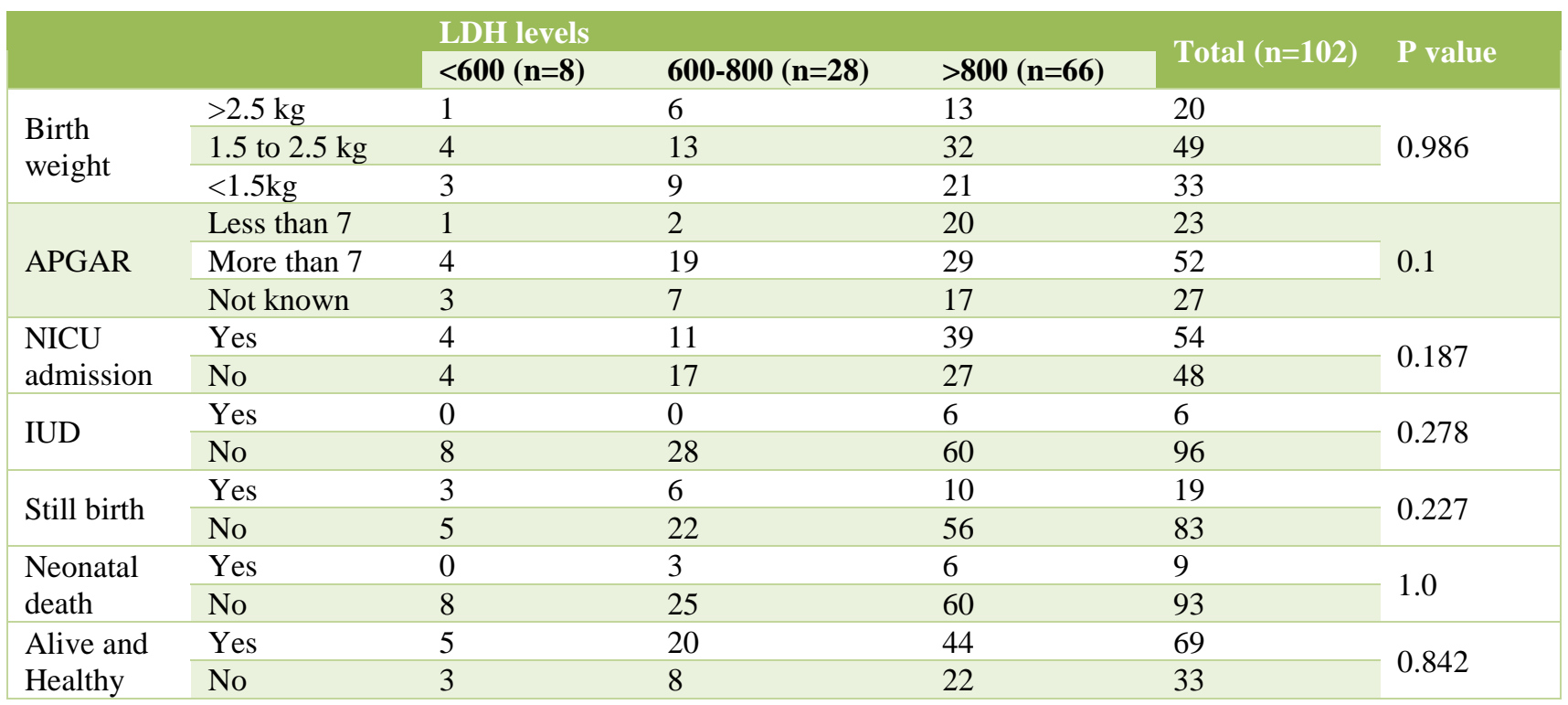

Table 3: LDH levels in preeclampsia and eclampsia patients presenting in different seasons.

\begin{tabular}{|c|c|c|c|c|c|c|}
\hline & & \multicolumn{3}{|c|}{ LDH levels } & \multirow[b]{2}{*}{ Total } & \multirow{2}{*}{ P value } \\
\hline & & $<600$ & $600-800$ & $>800$ & & \\
\hline \multirow{2}{*}{ March to May } & Preeclampsia & $1(11.1 \%)$ & $1(11.1 \%)$ & $7(77.8 \%)$ & 9 & \multirow{2}{*}{0.496} \\
\hline & Eclampsia & $2(10.5 \%)$ & $6(31.6 \%)$ & $11(57.9 \%)$ & 19 & \\
\hline \multirow{2}{*}{ June to Oct } & Preeclampsia & $2(9.5 \%)$ & $6(28.6 \%)$ & $13(61.9 \%)$ & 21 & \multirow{2}{*}{0.485} \\
\hline & Eclampsia & 0 & $4(28.6 \%)$ & $10(71.4 \%)$ & 14 & \\
\hline \multirow{2}{*}{ Nov to Feb } & Preeclampsia & $2(10 \%)$ & $6(30 \%)$ & $12(60 \%)$ & 20 & \multirow{2}{*}{0.8} \\
\hline & Eclampsia & $1(5.3 \%)$ & $5(26.3 \%)$ & $13(68.4 \%)$ & 19 & \\
\hline
\end{tabular}

Table 4: Age categories and LDH levels cross tabulation.

\begin{tabular}{|lllllll|}
\hline & & LDH levels & & & Total & P \\
value
\end{tabular}


Out of 102 cases, 8 cases had serum LDH levels of $<600$ IU/L, 28 cases had serum LDH levels between $600-800$ IU/L and 66 cases were $>800 \mathrm{IU} / \mathrm{L}$. LDH was raised to $>800 \mathrm{IU} / \mathrm{L}$ in most of the women with preeclampsia and eclampsia, (66 of 102 cases), but was not significant statistically $(\mathrm{p}=0.3)$. LDH raised to $>800 \mathrm{IU} / \mathrm{L}$ was seen more in the younger age group (28 of 41 cases in the age group of 18-22 years) (Table 4).

\section{DISCUSSION}

In the present study, majority of women with preeclampsia and eclampsia were of younger age group (18-27 years). This finding was also observed by Jaiswar et al in their study. ${ }^{4}$

In our study, there was no statistically significant association of serum LDH levels with gestational age at delivery, parity and obstetric outcome as opposed to the study of Jaiswar et al., who found most of the women were nulliparous and mean gestational age at delivery was significantly less in patients with increased serum LDH levels $(p=0.025)$. Jaiswar et al. also found association between poor obstetric outcome (low birth weight, IUGR, perinatal death and preterm births) and increasing levels of serum LDH. ${ }^{4}$

Even though serum LDH levels were elevated in our cases, it was not statistically significant. But more number of younger women in the age group of 18-22 years had elevated LDH levels of $>800 \mathrm{IU} / \mathrm{L}$. As elevated serum LDH is a prognostic marker in preeclampsia and eclampsia, and is associated with poor prognosis during antepartum, intrapartum and postpartum periods, such women with elevated LDH should be closely monitored. Raised LDH level is known to be associated with HELLP syndrome, DIC and also heart disease, thus long term follow up of these young women for cardiac diseases like myocarditis, myocardial infarction, ect, is necessary. ${ }^{8}$

There was no association between seasonal variation and occurrence of the disease observed in this study as opposed to a study by Magnus et al., in which there was a peak in occurrence of preeclampsia during winter. ${ }^{6}$

\section{CONCLUSION}

This study only showed that preeclampsia and eclampsia occurred most commonly in younger women. This study did not show any seasonal variation in the occurrence of preeclampsia and eclampsia, neither did it show any variation in serum LDH levels in patients presenting in different seasons. Young preeclamptic women with raised LDH levels not only need close monitoring during pregnancy and immediate postpartum period, but also require long term follow up.

Funding: No funding sources

Conflict of interest: None declared

Ethical approval: The study was approved by the Institutional Ethics Committee

\section{REFERENCES}

1. Andrews L, Patel N. Correlation of serum lactate dehydrogenase and pregnancy induced hypertension with its adverse outcomes. Int J Res Med Sci. 2016;4(5):1347-50.

2. Gary FC. Williams obstetrics / [edited by] Gary FC, Leveno KJ, Bloom SL, Spong CY, Dashe JS, Hoffman BL, Casey BM, Sheffield JS. 24 ${ }^{\text {th }}$ ed. United States: New York: McGraw-Hill Education/Medical; 2014.

3. Mary V, Chellatamizh M, Padmanaban S. Role of serum LDH in preeclampsia as a prognostic factor a cross sectional case control study in tertiary care hospital. Int J Reprod Contracept Obstet Gynecol. 2017;6(2):595.

4. Jaiswar SP, Gupta A, Sachan R, Natu SN, Shaili M. Lactic dehydrogenase: a biochemical marker for preeclampsia-eclampsia. J Obstet Gynecol India. 2011;61(6):645-8.

5. Umasatyasri Y, Van I, Shamita P. Role of LDH (Lactate dehydrogenase) in preeclampsia - eclampsia as a prognostic marker: An observational study. IAIM. 2015;2(9):88-93.

6. Magnus P, Eskild A. Seasonal variation in the occurrence of pre-eclampsia. BJOG: An Int J Obstet Gynaecol. 2001;108(11):1116-9.

7. Okafor UV, Ezegwui HU. Caesarean delivery in preeclampsia and seasonal variation in a tropical rainforest belt. J Postgrad Med. 2010;56:21-3.

8. Okafor UV, Efetie ER, Ekumankama O. Eclampsia and seasonal variation in the tropics-a study in Nigeria. Pan Afr Med J. 2009;2(1).

Cite this article as: Ciryam SS, Gomathy E. Study of serum lactate dehydrogenase level and seasonal variation in preeclampsia and eclampsia with its obstetric outcome. Int J Reprod Contracept Obstet Gynecol 2017;6:3533-6. 